\title{
Age and weight at puberty in tropical dairy criollo heifers with and without supplementary feeding
}

\section{Edad y peso a la pubertad en vaquillas criollo lechero tropical con y sin complementación alimenticia}

\author{
Víctor Hugo Severino-Lendechy ${ }^{1 *}$, Felipe Montiel-Palacios ${ }^{2}$, Ponciano Pérez-Hernández ${ }^{3}$ \\ ${ }^{1}$ Escuela Maya de Estudios Agropecuarios, Universidad Autónoma de Chiapas. Carretera Catazajá-Palenque Km 4, CP. 29980. \\ Catazajá, Chiapas \\ ${ }^{2}$ Facultad de Medicina Veterinaria y Zootecnia, Universidad Veracruzana. Circunvalación Esq. Yáñez s/n, Col. Unidad \\ Veracruzana, CP. 91710, Veracruz, Veracruz. \\ ${ }^{3}$ Colegio de Postgraduados, Campus Veracruz. Km 88.5 carretera Xalapa-Veracruz. Predio tepetates, CP. 91700. Municipio \\ Manlio Fabio Altamirano, Veracruz. \\ ${ }^{*}$ Corresponding author: vhseverino@hotmail.com
}

Scientific note received: August 18, 2016 accepted: February 16, 2017

\begin{abstract}
The effect of supplementary feeding on age and weight at puberty was evaluated in 79 pre-pubertal Tropical Dairy Criollo (TDC) heifers of 8 and 10 months of age, distributed in four treatments: T1 and T2) 8 month old heifers with and without supplementary feeding (WSF, $n=20$ ) and (NSF, $n=20$ ), respectively; T3 and T4) 10 month old heifers (WSF, $\mathrm{n}=20$ ) and (NSF, $\mathrm{n}=19$ ). Average age and weight at puberty in T2 and T4 was $20.4 \pm$ 0.5 months and $287.2 \pm 5.9 \mathrm{~kg}$ compared with $17.5 \pm 0.6$ months and $296.8 \pm 7.8 \mathrm{~kg}$ in T1 and T3 $(\mathrm{p}<0.05)$. The number, follicular diameter $(\mathrm{mm})$ and concentration of progesterone $\left(\mathrm{ng} \mathrm{mL}^{-1}\right)$ in blood was higher $(\mathrm{p}<0.05)$ in T1 and T3 compared to T2 and T4. Supplementary feeding decreases the age at puberty, increases weight gain, improves follicular development and increases blood progesterone concentration in TDC females.
\end{abstract}

Key words: Follicular dynamics, estrus, nutrition, ovulation, TDC

RESUMEN. Se evaluó el efecto de la complementación alimenticia sobre la edad y peso a la pubertad en 79 hembras Criollo Lechero Tropical (CLT) prepúberes de 8 y 10 meses de edad, distribuidas en cuatro tratamientos: T1 y T2) vaquillas de 8 meses con y $\sin$ complementación alimenticia (CCA, $n=20)$ y $(S C A, n=20)$, respectivamente; T3 y T4) vaquillas de 10 meses (CCA, $n=20)$ y (SCA, $n=19)$. La edad y peso a la pubertad en T2 y T4 fue de $20.4 \pm$ 0.5 meses y $287.2 \pm 5.9 \mathrm{~kg}$, en T1 y T3 fue de $17.5 \pm 0.6$ meses y $296.8 \pm 7.8 \mathrm{~kg}$. El número, diámetro folicular $(\mathrm{mm})$ y concentración de progesterona $\left(\mathrm{ng} \mathrm{mL}^{-1}\right)$ en sangre fue mayor $(\mathrm{p}<0.05)$ en T1 y T3. La complementación alimenticia disminuye la edad a la pubertad, incrementa la ganancia de peso, mejora el desarrollo folicular y aumenta concentración de progesterona en sangre de hembras CLT.

Palabras clave: Dinámica folicular, estro, nutrición, ovulación, CLT

\section{INTRODUCTION}

Puberty in the female bovine is the culmination of a series of reproductive events resulting in the presence of oestrus, accompanied by ovulation and normal luteal function. This physiological stage has economic and productive importance in the herd, since heifers with puberty at an early age give birth to their first calf at about the age of two, have lower production costs and produce more calves in their productive life (Evans and Rawlings 2010). Age at puberty is influenced by several factors, including nutrition, weight, breed, age, climate, and disease (Faure and Morales 2003). These factors are of importance in the tropics, because the characteristics of the environment itself cause puberty to occur 
in heifers after 30 months of age, which results in low reproductive efficiency by having their first birth between 42 and 48 months of age (Maquivar and Galina 2010). This has been reported in bovine genotypes of cebuine breeds, European breeds and their Bos taurus $x$ Bos indicus crosses (De Alba 2011). The first ones, although they have good adaptability to the tropics, have lost productivity and precocity (Abeygunawardena and Dematawewa 2004); the second ones are specialized European breeds that have difficulties adapting to tropical environments and the third ones, even though they have shown some improvement due to their hybrid vigor, do not offer a solution to the problem of tropical stockbreeding, due to their inconsistent production indexes (Maquivar and Galina 2010, De Alba 2011). An alternative to the above problem is the use of Tropical Dairy Criollo (TDC) cattle, to which greater precocity and adaptability have been attributed when compared to the predominant breeds in tropical regions (De Alba 2011).

The TDC deserves special attention, not only because it is an important genetic resource in Mexico, but also because its conservation and development are of vital importance as alternative productive processes in cattle herds of the tropics, through the use of their productive capacities (De Alba 2011). Based on the above, the aim of this study was to evaluate the effect of supplementary feeding on age and weight at puberty in 8 and 10 month old heifers, as well as on daily weight gain, follicular dynamics, ovulation rate and progesterone concentration in blood.

\section{MATERIALS AND METHODS}

\section{Geographical location of the production unit}

The study was carried out at a production unit (PU) located in Ixtacomitán, Centro, Tabasco, Mexico, located at $17^{\circ} 96^{\prime} 67^{\prime \prime} \mathrm{NL}$ and $92^{\circ} 96^{\prime} 67^{\prime \prime}$ $\mathrm{WL}$, at 10 masl, with a humid tropical climate and mean annual temperature and rainfall of $26.4{ }^{\circ} \mathrm{C}$ and $1500 \mathrm{~mm}$, respectively (García 1981).

\section{Characteristics of experimental TDC bovine fe- males}

We selected 79 pre-pubertal TDC females of 8 and 10 months of age, identified according to PU records, maintained with usual PU management in relation to feeding (grazing) and health measures (internal deworming every $180 \mathrm{~d}$ and external from two to three times a year; vaccination every six months against derringue, anthrax and blackleg. Females were identified with progressive numbering and assigned at random.

\section{Factors, treatments and experimental design}

The factors considered were: heifer age (8 and 10 months) and supplementary feeding (With and No). The treatments were: T1) calves of 8 months with supplementary feeding (WSF; $n=20$ ); T2) calves of 8 months without supplementary feeding (NSF; $n=20$ ); T3) calves of 10 months (WSF, $n=20$ ); And T4) calves of 10 months (NSF, $n=19)$. The experimental design used was a $2 \times 2$ factorial arrangement.

TDC calves ( $T 1$ and $T 3$ ) were maintained in pastures with signal grass (Brachiaria decumbens) and African star (Cynodon plectostachyus), and received supplementary feeding with balanced commercial feed containing $18 \%$ crude protein at a rate of $2 \mathrm{~kg}$ per animal $\mathrm{d}^{-1}$ and mineral salts provided ad libitum with $8 \%$ phosphorus, from their inclusion in the study until the heifers presented puberty. The NSF heifers (T2 and T4) had the same management as those of $T 1$ and $T 3$, except for the supplementary feeding.

The variables evaluated were initial weight, daily weight gain, total weight gain, weight and age at puberty, follicular dynamics and progesterone concentration in blood. Initial weight was determined by weighing the calves at the beginning of the study and then every $22 \mathrm{~d}$ until the end of the treatment; using this information, daily weight gain, total weight gain and weight at puberty were calculated. To determine the follicular dynamics, $22 \mathrm{~d}$ cycles were considered. The ovarian structures were examined by transrectal ultrasonography twice a week from the study start date to 
$17 \mathrm{~d}$, and continuously from days 18 to 22 in all heifers. Follicular dynamics were monitored using a Universal UMS 900 portable ultrasound with a 7.0- $\mathrm{MHz}$ transrectal transducer, which was rectally inserted and placed along the dorsal surface of the uterine horn. Subsequently, lateral movements were performed to examine the ovaries. The reproductive tract was not manipulated directly before or during the ultrasonographic examination (Ginther et al. 1989). The evaluation was performed until detecting ovulation in the females, which was considered as the onset of puberty. The follicles present and the presence of a dominant follicle (12 to $15 \mathrm{~mm}$ in diameter) were measured. The heifers that presented a dominant follicle underwent ultrasonography at 7 and $14 \mathrm{~d}$ later to confirm ovulation by detecting a corpus luteum $(\mathrm{CL})$. In case of not finding a CL, the evaluation was restarted every 22 d. Blood samples were taken from the females on the same days as the ultrasonography, by means of puncturing the coccygeal vein with a $21 \mathrm{G} \times 38 \mathrm{~mm}$ gauge needle and $6 \mathrm{ml}$ Vacutainer ${ }^{\circledR}$ tubes without anticoagulant. The samples were centrifuged at $2500 \mathrm{rpm}$ for $10 \mathrm{~min}$ in a period no longer than 4 $\mathrm{h}$, in order to separate the serum and make aliquots that were frozen at $-20^{\circ} \mathrm{C}$ until determination of the $\mathrm{P}_{4}$ concentration by solid phase radioimmunoassay. Serum progesterone concentration $\left(\mathrm{P}_{4} \geq 1 \mathrm{ng} \mathrm{mL}^{-1}\right.$ in two consecutive samples) was indicative of the presence and functionality of the $\mathrm{CL}$.

\section{Statistical analysis}

To determine the effect of treatment on daily weight gain, total weight gain, weight and age at puberty, analyzes of variance were performed in a $2 \times 2$ factorial arrangement, considering as the covariable initial weight, and the factors were: heifer age and supplementary feeding. Results of follicular activity and $\mathrm{P}_{4}$ serum concentration were evaluated by univariate repeated measures analysis of variance, considering as covariables initial weight, daily weight gain, total weight gain and weight at puberty. The ovulation rate was analyzed with a Chi-square test; to determine the effect of initial weight, weight gain, total weight gain, weight at puberty and treatment on ovulation rate, a logistic regression was performed. To determine the probability of presenting the first estrus according to the treatment assigned, a survival analysis was performed using the KaplanMeier method. All tests were performed using the SPSS statistical package.

\section{RESULTS AND DISCUSSION}

\section{Changes in body weight}

Initial weight of the heifers varied according to age (Table 1), being lower in heifers of 8 months than 10 months. Supplementary feeding (SF) improved $(p<0.05)$ weight gain and total weight gain with respect to NSF, as reported by Gasser et al. (2006d) and Maquivar et al. (2010). Results of weight gain and total weight gain (Table 1 ) are similar to those obtained in Maremmana creole breed heifers (Sargentini et al. 2007), but different from those obtained in females of the Avileña Negra-Ibérica breed (González-Stagnaro and De la Fuente-Martínez 2012), which is attributed to the particularities of breed and management (GonzálezStagnaro and De la Fuente-Martínez 2012).

\section{Age and weight at puberty}

The average age and weight at puberty of T2 and T4 heifers was $20.4 \pm 0.5$ months and $287.2 \pm$ $5.9 \mathrm{~kg}$ compared to $17.5 \pm 0.6$ months and $296.8 \pm$ $7.8 \mathrm{~kg}$ for T1 and T3 heifers $(\mathrm{p}<0.05)$. Therefore, WSF heifers presented puberty at a greater weight and younger age than NSF ones (Table 1). The benefits of improved heifer feeding on weight gain and age at puberty have been documented in Bos taurus (Gasser et al. 2006d), Bos indicus (Romano et al. 2007) and Bos taurus $\times$ Bos indicus breeds (Maquivar et al. 2010). An early increase in the frequency of LH pulses, larger follicles, a higher number of follicular waves, greater estrogen secretion, greater weight, and lower age at puberty have been observed in Bos taurus heifers supplemented with feed (Gasser et al. 2006a, 2006b, 2006c). However, the exact mechanisms by which SF and weight gains contribute to decreasing age at puberty are not well defined (Maquivar and Galina 2010, Perry 2012). 
Table 1. Distribution of TDC calves by age group and treatment.

\begin{tabular}{lcccc}
\hline Variable & \multicolumn{3}{c}{ Treatments } \\
\hline & $\mathrm{T} 1(8 \mathrm{~m}, \mathrm{WSF})$ & $\mathrm{T} 2(8 \mathrm{~m}, \mathrm{NSF})$ & $\mathrm{T} 3(10 \mathrm{~m}, \mathrm{WSF})$ & $\mathrm{T4}(10 \mathrm{~m}, \mathrm{NSF})$ \\
& $\mathrm{n}=20$ & $\mathrm{n}=20$ & $\mathrm{n}=20$ & $\mathrm{n}=19$ \\
\hline Initial weight $(\mathrm{kg})$ & $155.4 \pm 10.2^{a}$ & $154.7 \pm 10.3^{a}$ & $210.4 \pm 8.9^{b}$ & $208.5 \pm 7.8^{b}$ \\
Weight gain (g d $\left.{ }^{-1}\right)$ & $0.526 \pm 0.08^{a}$ & $0.326 \pm 0.03^{b}$ & $0.558 \pm 0.08^{c}$ & $0.333 \pm 0.02^{b}$ \\
Total weight gain (kg) & $154.1 \pm 7.3^{a}$ & $136.9 \pm 0.5^{b}$ & $117.7 \pm 5.5^{a}$ & $90.8 \pm 5.2^{b}$ \\
Weight at puberty (kg) & $295.1 \pm 7.5^{a}$ & $288.4 \pm 2.5^{b}$ & $298.6 \pm 8.2^{a}$ & $286.1 \pm 9.4^{b}$ \\
Age at puberty (months) & $17.7 \pm 0.8^{a}$ & $21.6 \pm 0.5^{b}$ & $17.3 \pm 0.5^{a}$ & $19.2 \pm 0.5^{c}$ \\
\hline
\end{tabular}

$a, b, c$ Different letter per row by age group indicates statistical difference $(p<0.05)$.

But SF in TDC calves is an effective tool to increase weight gain and reduce age at puberty. The weight and age at puberty obtained in TDC heifers are similar to those reported in criollo breeds such as the Maremmana (Sargentini et al. 2007) and the Parda de Montaña (Bodas et al. 2009), but larger than the Avileña Negra-Ibérica (González-Stagnaro and De la Fuente-Martínez 2012). Differences and similarities in age and weight at puberty of the Maremmana, Parda de Montaña and Avileña Negra-lbérica criollo breeds compared to the TDC can be attributed to factors such as the size, physical structure, management and nutritional status of calves during their pre-pubertal development before puberty (Maquivar et al. 2010, González-Stagnaro and De la FuenteMartínez 2012). This is related to the zootechnical purpose of each breed (González-Stagnaro et al. 2006, Maquivar and Galina 2010), considering that the first two breeds are for meat production and the Avileña Negra-lbérica is a dual-purpose breed, so these breeds have bigger size, a stronger physical structure and a different zootechnical management than the TDC which is intended for milk production.

Heifers fed only grass presented puberty three months later compared to WSF heifers $(20.4 \pm 0.5$ vs $17.5 \pm 0.6$ ) (Table 3 ), with a positive interaction between SF and age at puberty, indicating that age at puberty decreases by providing SF to females, which implies that it is better to supplement heifers at 10 than 8 months of age since the SF time is less. SFF decreases the age at puberty, directly affecting the economic and productive aspects, since heifers that reach puberty at a younger age (16 \pm 1 months) have a lower cost than those with a later age and produce more calves in their life than those who give birth to their offspring after three years (Patterson et al. 1992). Therefore, lowering the age at puberty determines a more efficient and prolonged productive life (Day and Grum 2005, Peter et al. 2009). In this regard, Kaplan-Meier found differences $(p<0.05)$ in age at puberty between calves of 8 and 10 months, indicating that the probability of heifers reaching puberty at a younger age is greater when they receive SF, showing a positive effect on the lowering of age at puberty, and it implies better weight gain in animals. Although information on age and weight at puberty in TDC is limited, it has been reported that this breed managed under grazing conditions reaches puberty at a younger age and lower weight compared to Bos taurus and Bos indicus (de Alba 2011). However, the results show that TDC is an early breed, in relation to what was reported in Bos taurus, Bos indicus and Bos taurus $\times$ Bos indicus under tropical conditions (Vite et al. 2007, Maquivar and Galina 2010).

\section{Follicular dynamics and ovulation}

SF in 8 and 10 month old heifers improved follicular dynamics, resulting in a greater $(p<0.05)$ number of follicles and size than those with NSF (Table 2). SF improved follicular dynamics, which coincides with the findings reported by Romano et al. (2007), who found that Bos indicus heifers fed with a high-energy diet had better follicular development than those fed with a low-energy diet, while Gasser et al. (2006a) found differences in the follicular development of Bos taurus heifers supplemented and not supplemented. The ovulation rate was the same for all heifers regardless of 
Table 2. Average number of follicles, follicular diameter and progesterone in blood by age group and treatment of TDC females (Mean \pm SD).

\begin{tabular}{lcccc}
\hline Variable & \multicolumn{4}{c}{ Treatments } \\
\hline & T1 (8 m, WSF) & T2 (8 m, NSF) & T3 (10 m, WSF) & T4 (10 m, NSF) \\
& $\mathrm{n}=20$ & $\mathrm{n}=20$ & $\mathrm{n}=20$ & $\mathrm{n}=19$ \\
\hline No. of follicles & $128 \pm 10.0^{a}$ & $97 \pm 5.0^{b}$ & $152 \pm 12.0^{c}$ & $115 \pm 6.0^{d}$ \\
Follicular diameter $(\mathrm{mm})$ & $10.8 \pm 2.1^{a}$ & $7.3 \pm 1.9^{b}$ & $12 \pm 2.5^{c}$ & $7.7 \pm 2.0^{b}$ \\
Progesterone in blood $\left(\mathrm{ng} \mathrm{mL} \mathrm{mL}^{-1}\right)$ & $1.59 \pm 0.06^{a}$ & $1.12 \pm 0.01^{b}$ & $1.69 \pm 0.27^{a}$ & $1.19 \pm 0.05^{b}$ \\
Ovulation rate (\%) & $100^{a}$ & $100^{a}$ & $100^{a}$ & $100^{a}$ \\
\hline
\end{tabular}

$a, b, c$, Different letter per row by age group indicates statistical difference $(p<0.05)$.

Table 3. Age at puberty of Tropical Dairy Criollo calves by age group and treatment (Mean $\pm \mathrm{SD})$.

\begin{tabular}{lccc}
\hline \multicolumn{4}{c}{ Age (months) } \\
\hline Treatment & 8 & 10 & Totals \\
\hline With supplementation & $17.7 \pm 0.8^{a}$ & $17.3 \pm 0.5^{a}$ & $17.5 \pm 0.6^{a}$ \\
Without supplementation & $21.6 \pm 0.5^{b}$ & $19.2 \pm 0.5^{b}$ & $20.4 \pm 0.5^{b}$ \\
Totals & $19.6 \pm 0.7$ & $18.2 \pm 0.5$ & $18.9 \pm 2.5$ \\
\hline a,b Different letter per row by age group indicates statistical difference \\
(p<0.05).
\end{tabular}

treatment (Table 2). However, those that received SF ovulated before those that did not, which differs from what was reported by Maquivar et al. (2010) with Bos taurus $x$ Bos indicus heifers with WSF and NSF that ovulated at an age of $673 \pm 146$ $\mathrm{d}$ with an average weight of $340 \mathrm{~kg}$, which was attributed to the weight gains and better body condition of the WSF animals. The difference in the results obtained may be due to the fact that most heifers require a specific weight to ovulate for the first time and reach puberty (Faure and Morales 2003, Perry 2012). The results show that the management and nutritional status of developing calves before puberty is important for better follicular growth and reproductive performance (Maquivar et al. 2010, González-Stagnaro and De la FuenteMartínez 2012).

\section{Progesterone production}

The $\mathrm{P}_{4}$ concentration in blood was higher ( $\mathrm{p}$
$<0.05)$ in the T1 and T3 heifers than in the T2 and T4 ones (Table 2). These results are similar to those observed in the Avileña Negra-lbérica breed before puberty (González-Stagnaro and De la Fuente-Martínez 2012), while Lents et al. (2011), in Bos taurus heifers of $9.1 \pm 0.1$ and $12.3 \pm 0.1$ months of age, reported differences in progesterone concentration between NSF females $\left(<1 \mathrm{ng} \mathrm{mL}^{-1}\right)$ with respect to WSF ones $\left(1.78 \pm 0.18 \mathrm{ng} \mathrm{mL}^{-1}\right)$. The effect of SF on the $\mathrm{P}_{4}$ concentration in heifers (Gasser et al., 2006b, Lents et al., 2008), as well as on weight gains and body condition, have been reported at the development stage before and after puberty (Maquivar et al. 2010, González-Stagnaro and De la Fuente-Martínez 2012).

Supplementary feeding decreases the age at puberty, by increasing daily weight gain, improves follicular development and increases the progesterone concentration in blood of 8 and 10 month old TDC bovine females.

\section{LITERATURA CITADA}

Abeygunawardena H, Dematawewa C (2004) Prepuberal and postpartum anestrus in tropical Zebu cattle. Animal Reproduction Science 82-83: 373-387.

Bodas R, López-Campos O, Mantecón AR (2009) Recría de terneras Parda de Montaña: alimentación y desarrollo productivo. Archivos de Zootecnia 58: 309-312. 
Day ML, Grum DE (2005) Breeding strategies to optimize reproductive efficiency in beef herds. Veterinary Clinics of North America: Food Animal Practice 21: 367-381.

De Alba J (2011) Los Criollos Lecheros Tropicales. In: El libro de los bovinos criollos de América, J. de Alba Martínez. Biblioteca Básica de Agricultura (Colegio de Postgraduados), Ediciones Papiro Omega. México. pp: 91-156.

Evans ACO, Rawlings NC (2010) Fisiología de la pubertad de terneros y terneras. Taurus, Bs. As., 12: 11-23. Disponible en: http://www.produccion-animal.com.ar/informacion_tecnica/cria/130fisiologia_pubertad.pdf. Data consulted: September 18, 2012.

Faure R, Morales C (2003) La pubertad de la hembra bovina: I. Aspectos fisiológicos. Revista Salud Animal 25: 13-19.

García E (1981) Modificaciones al sistema de clasificación climática de Koppen. 3a Ed. Instituto de Geografía, UNAM. DF. México. 143p.

Gasser CL, Behlke EJ, Grum DE, Day ML (2006a) Effect of timing of feeding a high-concentrate diet on growth and attainment of puberty in early-weaned heifers. Journal of Animal Science 84: 3118-3122.

Gasser CL, Bridges GA, Mussard ML, Grum DE, Kinder JE, Day ML (2006b) Induction of precocious puberty in heifers III: Hastened reduction of estradiol negative feedback on secretion of luteinizing hormone. Journal of Animal Science 84: 2035-2041.

Gasser CL, Burke CR, Mussard ML, Behlke EJ, Grum DE, Kinder JE, et al. (2006c) Induction of precocious puberty in heifers II: Advanced ovarian follicular development. Journal of Animal Science 84: 2042-2049.

Gasser CL, Grum DE, Mussard, ML, Fluharty FL, Kinder JE, Day ML (2006d) Induction of precocious puberty in heifers I: Enhanced secretion of luteinizing hormone. Journal of Animal Science 84: 2050-2056.

Ginther OJ, Kastelic JP, Knopf L (1989) Composition and characteristics of follicular waves during the bovine estrous cycle. Animal Reproduction Science 20: 187-200.

González-Stagnaro C, Rodríguez-Urbina MA, Goicochea-Llaque J, Madrid-Bury N, González-Villalobos D (2006) Crecimiento pre-destete en hembras bovinas doble propósito. Revista Científica, Facultad de Ciencias Veterinarias-LUZ 16: 288-296.

González-Stagnaro C, de la Fuente-Martínez J (2012) Pubertad en novillas de la raza Española Avileña-Negra Ibérica. Revista Científica, Facultad de Ciencias Veterinarias-LUZ 22: 17-23.

Lents CA, Randel RD, Stelzleni AM, Caldwell LC, Welsh TH Jr (2011) Function of the corpus luteum in beef heifers is affected by acute submaintenance feeding but is not correlated with residual feed intake. Journal of Animal Science 89: 4023-4031.

Maquivar M, Galina CS (2010) Factors Affecting the readiness and preparation of replacement heifers in tropical breeding environments. Reproduction of Domestic Animals 45: 937-942.

Maquivar MG, Galina CS, Galindo JR, Estrada S, Molina R, Mendoza GD (2010) Effect of protein supplementation on reproductive and productive performance in Bos indicus $\times$ Bos taurus heifers raised in the humid tropics of Costa Rica. Tropical Animal Health Production 42: 555-560.

Patterson DJ, Perry RC, Kiracofe GH, Belows RA, Staigmiller RB, Corah LR (1992) Management considerations in heifer development and puberty. Journal of Animal Science 70: 4018-35.

Perry GA (2012) Physiology and endocrinology symposium: Harnessing basic knowledge of factors controlling puberty to improve synchronization of estrus and fertility in heifers. Journal of Animal Science 90: 11721182. 
Peter AT, Vos PLAM, Ambrose DJ (2009) Postpartum anestrus in dairy cattle. Theriogenology 71: 13331342.

Romano MA, Barnabe VH, Kastelic JP, de Oliveira CA, Romano RM (2007) Follicular dynamics in heifers during pre-pubertal and pubertal period kept under two levels of dietary energy intake. Reproduction of Domestic Animals 42: 616-622.

Sargentini C, Bozzi R, Diaz-Rivera P, Giorgetti A, Martini A, Lupi P, et al. (2007) Onset of puberty in Maremmana heifers. Journal of Animal Science 6: 385-394.

Vite C, López R, García-Muñiz JG, Ramírez R, Ruíz A, López R (2007) Producción de leche y comportamiento reproductivo de vacas de doble propósito que consumen forrajes tropicales y concentrados. Veterinaria México 38: 63-79. 
